\title{
Haemostatic Agent as New lonophore for Selective Determination of Copper in Environmental Samples and Pharmaceutical Formulations.
}

\author{
Nashwa M. H. Rizk ${ }^{1 *}$, Fouad. A. Asswadi ${ }^{2}$, Ayman M. M. Sawan ${ }^{3}$ and Fathy A. Elsayed ${ }^{2}$ \\ 1 Environmental Biotechnology Department, Genetic Engineering and Biotechnology \\ Research Institute (GEBRI), University of Sadat City, Sadat City, Egypt. \\ ${ }^{2}$ Chemistry Department, Faculty of Sciences, Minufiya University, Egypt \\ ${ }^{3}$ Chemistry Department, Alghad International Colleges for Applied Medical Sciences, Almadina \\ Almonawarah Saudi Arabia. Permanent address, Ministry of Education, Egypt.
}

*Corresponding author: e-mail; nashwa.rizk@gebri.usc.edu.eg

\begin{abstract}
The construction and electrochemical response characteristics of poly vinyl chloride (PVC) membrane sensors for the determination of copper were described. The sensors are based on using of ethamsylate as an ionophore and dioctylphethalate (DOP) as a plasticizer in the PVC matrix. Conventional and graphite membrane sensors were prepared and the performance characteristics are evaluated according to IUPAC recommendations, reveal fast, stable and linear response for copper over the concentration range $1 \times 10^{-6}-1 \times 10^{-2} \mathrm{M}$ and $7 \times 10^{-5}-1 \times 10^{-2} \mathrm{M}$ with cationic slopes of 29.5 and $27.8 \mathrm{mV}$ per concentration decade at $\mathrm{pH} 5$ for conventional and graphite membrane sensors respectively. The potentiometric selectivity data revealed no interference from common cations. The direct potentiometric determination of copper using the proposed sensors gave average recoveries of $99.89 \pm 0.9$ and $100.04 \pm 1.1$ for the conventional and graphite sensors, respectively. The sensors are used for direct measurement of copper content in industrial waste water, metal alloys samples from copper factories and pharmaceutical formulations. The developed method was found to be simple, accurate and precise when compared with a reported atomic absorption method.
\end{abstract}

\section{INTRODUCTION}

The introduction of new ion selective electrodes (ISEs) has promoted fundamental developments in potentiometry (Jain, et. al, 1997). Copper is the third most abundant trace element for human, following iron and zinc. Copper has many applications in industry (Greenwood and Earnshow, 1984) biological and medical systems (Marston, 1952; Dadfarnia, and M. Shamsipur; 1992). It has relatively non-toxic to mammals, but the intake of large quantities can be toxic. The toxicity is generally attributed to the formation of the aquo-complexes of copper ion (Sadeghi, et. al, 2003). The sources of copper poisoning include beverages from vending machines, brass or copper vessels and sometimes water supplies (Richter et. al., 2001). Thus the development of simple, reliable, and low cost techniques for copper determination is essential. Methods in current use for copper quantification in different matrixes include, voltammetry (Janata and Růžička, 1982), spectrophotometry (Asan, et al 2001; Ahmed , et. al 2002), inductively coupled plasma/mass spectrometry (Jacintho, et.al, 1981; Zagatto, et. al, 1983), potentiometry (Hu, et. al., 1982), atomic absorption spectrometry (Hassan, 1984; Fang, et. al. 1984; Wolf and Stewart, 1979), and stripping voltammetry (Stankovic, et. al., 2011). The commercially used solid 
state copper electrode based on $\mathrm{CuS}-\mathrm{Ag}_{2} \mathrm{~S}$ has been used for the determination of copper ion although the $\mathrm{Cd}^{2+}, \mathrm{Fe}^{3}, \mathrm{Hg}^{2+}, \mathrm{Ag}^{+}, \mathrm{S}^{2-}$ and $\mathrm{Cl}^{-}$ions seriously interfere.

Several ionophores have been suggested for the preparation of copper membrane selective sensors (Table 1), some of them including porphyrins (Gupta, et al, 2006), ethambutol-copper (II) complex (Gupta, et al, 2003), dithioacetal (Abbaspour, and Kamyabi, 2002) dithiocarbamate (Kamata, et al, 1989), dithioaniline (Gholivand, and Nozari, 2001), macrocyclic diamides (Shamsipur, et al, 1999), thiohydrazone and thiosemicarbazone (Gismera, et al 1999), thioand dithiosalicylic acid (Gismera, et al 2003), 1,10-phenanthroline (Marzouk, et al, 2003), phenylglyoxal-alpha-monoxime (Firooz, et al, 2002), Schiff's base (Poursaberi, et al, 2001) cyanocopolymers (Gupta, and M. J. D'arc, 2000, 2001; Jain, et al, 2005), cyclic tetrapeptide derivatives (Hassan, et al, 2005), thiacrown ethers (Brzozka, 1988), pyrimidinethione derivatives (Abbaspour and Moosavi, 2002), hydrotris(3isopropyrazolyl)methane (Yoshimoto et al,
2003), chelates of copper with acetylacetone, ethylacetoacetate and salicyldehyde (Jain, et al, 2005), EDTA complex (Reynold, 1993) and ion carrier (Hassan, et al, 2003).

Ethamsylate or cyclonamine (diethylammonium, 2,5-dihydroxybenzenesulfonate) is a haemostatic agent commonly used in the prevention and control of haemorrhage from small blood vessels (Fig. 1) (Reynold, 1993). Recently, some drugs are used as carriers for the determination of some cations ((Hassan, et al, 2003; Rizk, et al, 2009). Because of the presences of some functional groups in the chemical structure of the drug which are valuable and attractive for the reaction with cations. In the present work, conventional and graphite membrane electrode for copper ion were constructed and the performance characteristics were studied. The sensors are based on using ethamsylate as neutral ionophore and dioctyl phethalate as a plasticizer in PVC matrix. The sensors possess the advantages of simple design, fast response time, near-Nernstian slop and high selectivity over many different metal cations

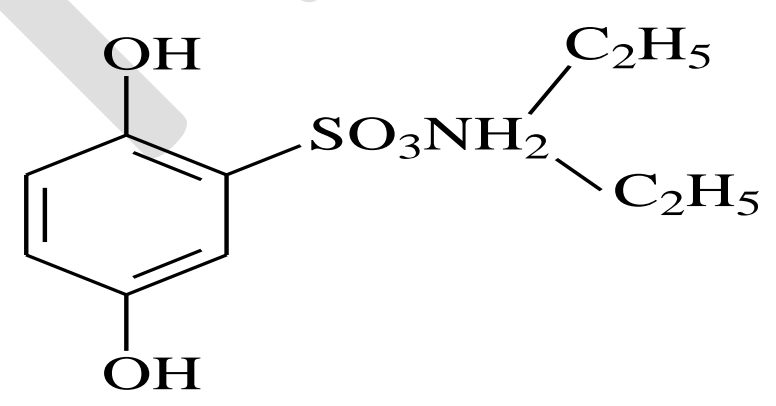

Fig. 1. Chemical structure of Ethamsylate. 
Table 1 General performance characteristics of some potentiometric copper membrane sensors.

\begin{tabular}{|c|c|c|c|c|c|}
\hline Ionophore & $\begin{array}{l}\text { Linear } \\
\text { Range (M) }\end{array}$ & $\begin{array}{l}\text { Lower } \\
\text { limit of } \\
\text { detection } \\
\text { (M) }\end{array}$ & $\begin{array}{c}\text { Slope } \\
\text { (mV/decad) }\end{array}$ & Interferent (M, Selectivity) & Ref \\
\hline Dithiocarbamate & $1 \times 10^{-6}-1 \times 10^{-1}$ & $4 \times 10^{-7}$ & $28-29$ & $\begin{array}{c}\mathrm{Cd}^{2+}-2.1, \mathrm{Co}^{2+}-1.9, \mathrm{Mn}^{2+}-2.4 \\
\mathrm{Mg}^{2+}-2.8 \\
\mathrm{Ag}^{+}-0.6, \mathrm{Hg}^{2+}-1.3\end{array}$ & $\begin{array}{l}\text { (Kamata, et al, } \\
\text { 1989) }\end{array}$ \\
\hline Dithioacetal & $3 \times 10^{-6}-5 \times 10^{-}$ & $1 \times 10^{-6}$ & $29 \pm 1$ & $\mathrm{Ag}^{+}-0.6, \mathrm{Hg}^{2+}-1.3$ & $\begin{array}{l}\text { (Abbaspour, and } \\
\text { Kamyabi, } 2002\end{array}$ \\
\hline Dithioaniline & $7 \times 10^{-7}-5 \times 10^{-}$ & $6 \times 10^{-7}$ & $30 \pm 1$ & $\begin{array}{c}\mathrm{Hg}^{2+}-3.5, \mathrm{Ag}^{+}-4.01, \mathrm{Fe}^{2+}-3.27 \\
\mathrm{~Pb}^{2+}-0.28\end{array}$ & $\begin{array}{l}\text { (Gholivand, and } \\
\text { Nozari, 2001) }\end{array}$ \\
\hline $\begin{array}{l}\text { Thia crowm } \\
\text { ethers }\end{array}$ & $1 \times 10^{-5}-1 \times 10^{-1}$ & $1.4 \times 10^{-7}$ & 22.3 & $\begin{array}{c}\mathrm{Cd}^{2+}-1.5, \mathrm{Co}^{2+}-1.0, \mathrm{Ni}^{2+}-1.4, \mathrm{~Pb}^{2+} \\
+0.1\end{array}$ & (Brzozka, 1988) \\
\hline $\begin{array}{l}\text { Ethambutol- } \\
\text { copper(II) } \\
\text { complex }\end{array}$ & $\begin{array}{c}7.9 . \times 10^{-6}- \\
1 \times 10^{-1}\end{array}$ & $7.0 \times 10^{-6}$ & 29.9 & $\begin{array}{c}\mathrm{Hg}^{2+}-0.1, \mathrm{Na}^{+}-0.48, \mathrm{~K}^{+}-0.2 \\
\mathrm{Co}^{2+}-0.87, \mathrm{~Pb}^{2+}-0.81, \mathrm{Ni}^{2+}-0.59 \\
\mathrm{Al}^{3+}-0.68\end{array}$ & $\begin{array}{c}\text { (Gupta, et al, } \\
\text { 2003) }\end{array}$ \\
\hline $\begin{array}{l}\text { Macrocyclic } \\
\text { diamides }\end{array}$ & $\begin{array}{c}3.2 \times 10^{-5}-1 \times 10^{-} \\
1\end{array}$ & 1. $2 \times 10^{-5}$ & 30 & $\begin{array}{c}\mathrm{Na}^{+}-0.48, \mathrm{~K}^{+}-0.88, \mathrm{Hg}^{2+}-2.4, \mathrm{Cd}^{2+} \\
-1.58, \mathrm{~Pb}^{2+}-2.2, \mathrm{Ni}^{2+}-2.01, \mathrm{Zn}^{2+}- \\
2.3, \mathrm{Sr}^{2+} \\
-1.03, \mathrm{CS}^{+}-0.79 \\
\mathrm{Ca}^{2+}-1.63\end{array}$ & $\begin{array}{l}\text { (Shamsipur, et } \\
a l, \text { 1999) }\end{array}$ \\
\hline $\begin{array}{l}\text { Clycic } \\
\text { tetrapeptide } \\
\text { derivatives }\end{array}$ & $\begin{array}{c}3.1 \times 10^{-6}- \\
1 \times 10^{-2}\end{array}$ & $2.1 \times 10^{-6}$ & 30.3 & $\begin{array}{c}\mathrm{Li}^{+}-5.1, \mathrm{Na}^{+}-5.15, \mathrm{~K}^{+}-5.1, \mathrm{CS}^{+}- \\
\text {4.3, } \mathrm{Ca}^{2+}-3.4, \mathrm{Al}^{3+}-4.06, \mathrm{Mg}^{2+}- \\
\text { 3.22, } \mathrm{Ag}^{+}-3.09, \mathrm{Sr}^{2+}-2.82, \mathrm{Fe}^{3+}- \\
3.2, \mathrm{Fe}^{2+}-2.84, \mathrm{Mn}^{2+}-2.69, \mathrm{Ba}^{2+}- \\
\text { 3.00, } \mathrm{Hg}^{2+}-2.52, \mathrm{Co}^{2+}-2.71, \mathrm{Ni}^{2+} \\
\text { 2.52, } \mathrm{Zn}^{2+}-1.70, \mathrm{Cd}^{2+}-2.39, \mathrm{~Pb}^{2+} \\
-0.52 . \\
\mathrm{Li}^{+}-5.51, \mathrm{Na}^{+}-4.3, \mathrm{~K}^{+}-4.41, \mathrm{CS}^{+}- \\
\text {4.42, } \mathrm{Ca}^{2+}-3.0, \mathrm{Al}^{3+}-3.97, \mathrm{Mg}^{2+}- \\
\text { 2.85, } \mathrm{Ag}^{+}-2.6, \mathrm{Sr}^{2+}-2.70, \mathrm{Fe}^{3+}- \\
\text { 3.06, } \mathrm{Fe}^{2+}-3.05, \mathrm{Mn}^{2+}-2.82, \mathrm{Ba}^{2+}- \\
\text { 3.10, } \mathrm{Hg}^{2+}-2.39, \mathrm{Co}^{2+}-2.60, \mathrm{Ni}^{2+} \\
\text { 2.52, } \mathrm{Zn}^{2+}-1.52, \mathrm{Cd}^{2+}-2.15, \mathrm{~Pb}^{2+}- \\
0.39 .\end{array}$ & $\begin{array}{l}\text { (Hassan, et al, } \\
\text { 2005) }\end{array}$ \\
\hline & $10^{-7.6}-10^{-3.2}$ & $10^{-7.9}-10^{-6.3}$ & 68.7 & $\begin{array}{c}\mathrm{Pb}^{2+}+0.61, \mathrm{Mg}^{2+}+0.18, \mathrm{Cd}^{2+} \\
+0.03, \mathrm{Ca}^{2+}-+0.29, \mathrm{Al}^{3+}+0.32, \mathrm{Fe}^{3+} \\
-1.16 .\end{array}$ & \\
\hline $\begin{array}{l}\text { Ethamsylate, } \\
\text { Conventional } \\
\text { sensor }\end{array}$ & $1 \times 10^{-6}-1 \times 10^{-2}$ & $5 \times 10^{-7}$ & 29.5 & $\begin{array}{c}\mathrm{Na}^{+}-2.69, \mathrm{~K}^{+}-2.33, \mathrm{Ag}^{+}-2.28, \mathrm{NH}_{4}^{+-} \\
2.46, \\
\mathrm{CS}^{+}-1.07, \mathrm{~Pb}^{2+}-2.17, \mathrm{Mg}^{2+}-3.33 \\
\mathrm{Ca}^{2+}-0.32, \mathrm{Co}^{2+}-1.55, \mathrm{Cd}^{2+}-1.25 \\
\mathrm{Ni}^{2}-1.04, \mathrm{Fe}^{2+} \\
-1.37, \mathrm{Sr}^{2+}-1.74, \mathrm{Zn}^{2+}-1.49, \mathrm{Mn}^{2+}- \\
1.44, \mathrm{Ce}^{3+}-1.56, \mathrm{Al}^{3+}-2.85, \mathrm{Fe}^{3+} \\
1.92 .\end{array}$ & This work \\
\hline Graphite sensor & $7 \times 10^{-5}-1 \times 10^{-2}$ & $1 \times 10^{-6}$ & 27.8 & 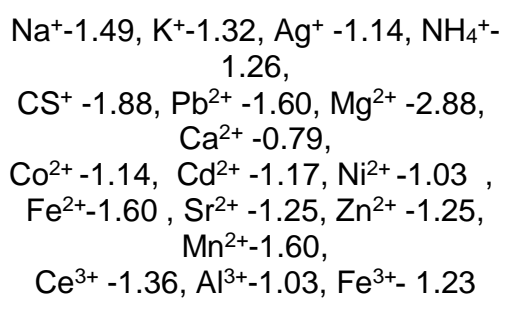 & 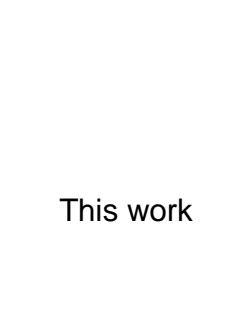 \\
\hline
\end{tabular}




\section{EXPERIMENTAL}

\section{Apparatus and reagents.}

Potentiometric measurements at $25+1^{\circ} \mathrm{C}$ were made with an Orion digital ionanalyser (model, 420A) using conventional and coated graphite sensor with ethamesylate as ionophore dispersed in PVC matrix and plasticizer as solvent mediater. A copper membrane was used in conjunction with an Orion 90-02, $\mathrm{Ag}-\mathrm{AgCl}$ double-junction reference electrode containing $10 \%(\mathrm{w} / \mathrm{v})$ $\mathrm{KNO}_{3}$ solution in the outer compartment. The cell assembly for the measurement of potential is $\mathrm{Ag} / \mathrm{AgCl} / \mathrm{KCl}\left(10^{-1} \mathrm{M}\right), \mathrm{KNO}_{3} \quad 10^{-1} \mathrm{M} /$ sample test solution//sensor membrane//internal filling solution $/ \mathrm{AgCl} / \mathrm{Ag}$. Adjustment of the $\mathrm{pH}$ was made with an Orion 91-20 combination glass electrode. Atomic absorption spectrometric measurements of $\mathrm{Cu}^{2+}$ were made with PerkinElmer spectrometer (model 3100) using recommended optimum conditions (Hassan, 1984). Copper alloys samples were digested in a Microwave Sample preparation System (Type MDS-2000), CEM Cooperation.

All chemicals were of analyticalreagent grade, unless otherwise stated, and bidistilled deionized water was used throughout. Ethamesylate was obtained from Sigma Chem. Co. (St. Louis, MO., USA). Nitrophenyl octyl ether (o-NPOE), dioctylphethalate (DOP), dioctylsebacate (DOS), tetrahydrofuran (THF) were obtained from Aldrich Chemical Co. (Milwaukee, Wisconsin, USA). Aqueous $10^{-2}-10^{-6} \mathrm{M}$ copper solutions were freshly prepared by accurate dilutions of a standard $10^{-1} \mathrm{M}$ stock drug solution by using $0.02 \mathrm{M}$ borate buffer $\mathrm{pH}$ 5. Carbon rods (F-purity) were obtained from Ultra Carbon Co. (Bay City, MI, USA).

\section{Preparation of conventional sensor}

The cocktail was prepared by mixing $2 \mathrm{mg}$ portion of ethamsylate ionophore mixed in a glass Petri dish $(5 \mathrm{~cm}$ diameter) with $132 \mathrm{mg}$ of dioctyl phthalate (DOP) and 66 mg of poly (vinyl chloride) (PVC) (Hassan and Marzouk, 1994; Rizk, et al, 1994). The mixture was dissolved in a $5 \mathrm{ml}$ of tetrahydrofuran (THF). The Petri dish was covered, and left to stand overnight to allow slow evaporation of the solvent at room temperature. A master PVC membrane (0.1 $\mathrm{mm}$ thickness) was obtained. The internal reference solution was prepared by mixing equal volumes of $1 \times 10^{-2} \mathrm{M} \mathrm{KCl}$ and $\mathrm{CuCl}_{2}$.

\section{Preparation of graphite sensor}

A rod of spectrographic graphite (5mm in diameter and $15 \mathrm{~mm}$ long) was inserted in a polyethylene sleeve, and about 3 $\mathrm{mm}$ of the other end of the protruded rod served as a measuring surface (Rizk, and Othman, 2005). This end of the rod was washed with acetone, dried in air for $3 \mathrm{~h}$, and dipped rapidly into a homogeneous coating of the previous cocktail. The solvent was allowed to evaporate in air after each dipping, and the dipping process was repeated 6 - 8 times to supply for a uniform membrane on the surface of the graphite rod. Before use, the coated graphite rod was soaked for $2 \mathrm{~h}$ in a $1 \times 10^{-2} \mathrm{M}$ aqueous copper solution. One drop of mercury was added in the polyethylene sleeve to ensure electrical contact with the connection cable. The sensors were conditioned by soaking in a $1 \times 10^{-2} \mathrm{M}$ copper solution for $9 \mathrm{~h}$, and stored in the same solution when not in use.

\section{Calibration of copper membrane sensors}


The membrane sensors were calibrated by immersion in a $1 \times 10^{-6}-1 \times 10^{-1} \mathrm{M}$ copper chloride solution with $0.01 \mathrm{M}$ acetate buffer, $\mathrm{pH} 5$. A $1.0 \mathrm{ml}$ aliquot of each solution was transferred into a $50 \mathrm{ml}$ beaker containing $9 \mathrm{ml}$ of a $00.01 \mathrm{M}$ acetate buffer solution $\mathrm{pH} 5$. Conventional and graphite copper sensors were immersed and allowed to equilibrate with constant stirring in conjunction with an Orion reference electrode. The sensors were washed with bidistilled deionized water between measurements. The electrode potential was recorded as a function of the copper concentration. The obtained calibration plot was used for subsequent measurements of unknown copper concentration under the same conditions.

\section{Sensor Selectivity}

The potentiometric selectivity coefficient ( ${ }^{\mathrm{Pot}} \mathrm{Cu}(I I), B$ of the copper sensors was measured by the separate solutions method (Rizk, et al, 2009; Umezawa, et al, 2000). In this method, the potentials of $10^{-3} \mathrm{M}$ concentration of both copper and the interfering species in $0.02 \mathrm{M}$ acetate buffer of $\mathrm{pH} 5$ were determined. The selectivity coefficients were calculated using the following equation.

$$
\begin{aligned}
& \log \left(K_{C u}^{P} \underset{(I I), B}{o t}\right)=\left(\mathrm{E}_{\mathrm{Cu}(I)}-\mathrm{E}_{\mathrm{B}}\right) / \mathrm{S}-\left[1+\mathrm{Z}_{\mathrm{Cu}(\mathrm{II})} / \mathrm{Z}_{\mathrm{B}}\right] \quad \log \\
& \mathrm{Cu}(\mathrm{II})
\end{aligned}
$$

Where $E_{C u}$ and $E_{B}$ are the potential readings observed after 1 min of exposing the sensor to the same concentration of copper and interferents, respectively, in separate solutions and $S$ is the slope of the copper calibration graph ( $\mathrm{mV} /$ concentration decade).

\section{Determination of copper in waste water}

Six waste water samples were collected (Egyptian copper company). Each solution was mixed with nitric acid, then dilution by acetate buffer $\mathrm{pH}$ 5. Mixtures were transferred to a $100 \mathrm{ml}$ volumetric flasks and diluted to the mark with $0.01 \mathrm{M}$ acetate buffer of $\mathrm{pH}$ 5. The e.m.f of the sensors were measured as described above and compared with the calibration plot. Alternatively, the standard addition technique was used by monitoring the potential of $50 \mathrm{ml}$ sample test solution before and after addition of $0.50 \mathrm{ml}$ of standard $0.01 \mathrm{M}$ copper chloride solution. The results obtained were compared with data obtained by atomic absorption method.

\section{Determination of copper in alloys}

Five alloy samples are collected (Egyptian copper company) and digested (using a Microwave Sample preparation System (Type MDS-2000)),

(CEM Cooperation, with nitric acid. The samples were transferred to $50 \mathrm{ml}$ to volumetric flasks and diluted to the mark with $0.01 \mathrm{M}$ acetate buffer of $\mathrm{pH} 5$. The potentional of the sensors were measured as described above and compared with the calibration plot. Alternatively, the standard addition technique was used by monitoring the potential of $20 \mathrm{ml}$ sample test solution before and after addition of $0.50 \mathrm{ml}$ of standard $0.01 \mathrm{M}$ copper chloride solution. The results obtained were compared with data obtained by atomic absorption method.

\section{Determination of copper in pharmaceutical formulations}

A homogenized powder was prepared from 10 accurately weighed drug capsules containing copper. An appropriate amount of this powder $(0.200 \mathrm{~g})$ was transferred into a $100-\mathrm{mL}$ volumetric flask. Dissolution of the drug was assisted by means of a magnetic stirrer. The solution was then 
diluted to the mark with water and the proposed electrode determined copper content by using the calibration method as mentioned before. The concentration of copper in samples were confirmed by applying atomic absorption method (Hassan, et al, 1984).

\section{RESULTS AND DISCUSSION}

\section{Composition of the electrodes}

The capability of ethamsylate as a very suitable $\mathrm{Cu}^{2+}$ ion complexing agent is examined for the construction of a new copper (II) ion-selective electrode. The influence of the membrane composition on the potential response of the $\mathrm{Cu}^{2+}$ ion-selective electrode was investigated. The critical response characteristics of the electrodes were assessed according to IUPAC recommendations (IUPAC, 1995).

From Table 2, five membrane compositions were investigated, the results showed that the electrodes made by membrane III with $3 \%$ ethamsylate as ionophore, exhibit the best performance characteristics (for conventional; slope 29.5 $\mathrm{mV} /$ decade, usable concentration range at $25^{\circ} \mathrm{C} 1 \times 10^{-6}-1 \times 10^{-2} \mathrm{M}$; for graphite; slope 29.5 $\mathrm{mV} /$ decade, usable concentration range at 25 $\left.{ }^{\circ} \mathrm{C} 7 \times 10^{-5}-1 \times 10^{-2} \mathrm{M}\right)$. Other membranes exhibit slopes ranging between 28.5-29.1 $\mathrm{mV} /$ decade and 25.8-27.1 mV/decade for conventional and graphite membrane electrodes. The optimum relative amounts of PVC, DOP and TPBderivative (1-10\%) as an additives suitable for the construction of the copper ion-selective electrodes were investigated.

Table 2 Composition of conventional and graphite PVC copper membrane sensors.

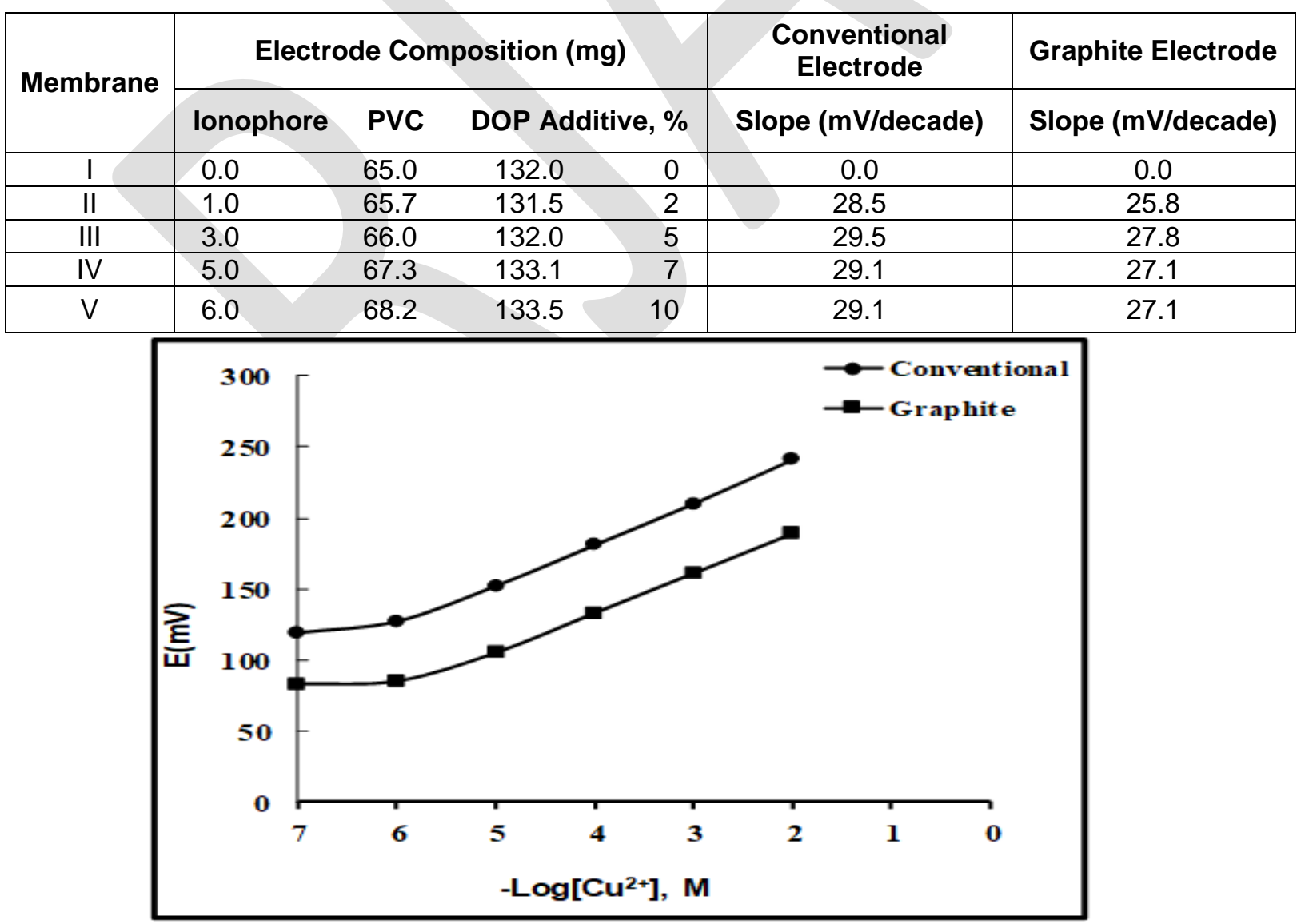

Fig. 2 Potentiometric response of copper PVC membrane sensors. 
Tetraphenylborate was added to the membrane composition to see if it can improve the performance characteristics of the sensors or not. The results obtained indicated that there is an improvement in the electrodes characteristics, e.g., sensitivity (response time without additive, $30 \mathrm{~s}$ for conventional; $40 \mathrm{~s}$ and for graphite and response time with 5\% additive, $10 \mathrm{~s}$ for conventional; $15 \mathrm{~s}$ and for graphite) and lifetime (without additive; 3 weeks for conventional; 2 weeks for graphite and lifetime with $5 \%$ additive; 4 weeks for conventional; 3 weeks for graphite) of the electrodes. The concentration of the internal solution $\mathrm{CuCl}_{2}$ in the electrode was changed from $1 \times 10^{-2}$ to $1 \times 10^{-6} \mathrm{M}$ and the potential response of the copper ion selective electrode was measured. It was found that variation of the concentration of the internal solution does not cause any significant difference in the potential response of the electrodes. A $1.0 \times 10^{-}$ ${ }^{3} \mathrm{M}$ concentration of internal solution is quite appropriate for smooth functioning of the electrode.

The optimum equilibration time for the membrane electrode is $9 \mathrm{~h}$. It generates stable potentials when placed in contact with $\mathrm{Cu}^{2+}$ solutions. The emf response of the membrane at varying concentrations of copper indicates a rectilinear range from $1 \times 10^{-6}$ to $1 \times 10^{-2} \mathrm{M}$ as limit of detection which determined from the intersection of the two extrapolated segments of the calibration graph. All performance characteristics of the sensors are compiled in Table 3. Figure 2 represent the calibration

\section{Response time and life time}

The response time of the sensor was determined by measuring the time required to curves of conventional and graphite electrodes.

The improvement in the performance characteristics of the sensors were attempted by the addition of different plasticizers to the membranes. The addition of plasticizers not only improves the workability of the membranes, but also contributes significantly towards the improvement in the working concentration range, stability and shelf life of the sensor. However, the selectivity remains usually unaffected and mainly depends on the metal-ionophore interaction. The plasticizer to be used in membranes should exhibit high lipophilicity, high molecular weight, low tendency for exudation from the polymer matrix, low vapor pressure and high capacity to dissolve the substrate and other additives present in the membrane. Additionally, its viscosity and dielectric constant should be adequate. Thus, three plasticizers namely, DOP, DBS, and o-NPOE were added in an attempt to improve the performance of the sensors. The performance characteristics of the membranes without ionophore were investigated and no potential was generated. The suggested mechanism for the proposed copper (II) ionophore is as follows: copper (II) forms sable complex with ethamsylate in a 1:2 copper (II) to drug ratio. The mechanism was proven by applying Job's method which is extremely versatile approach to the determination of reaction stoichiometries (Taylor, 1987).

achieve a steady potential for plasticizer DOP improved the response time to the maximum extent. The response time of the two 
membranes of ethamsylate with plasticizer DOP and $3 \%$ additive are found to be 10 and $15 \mathrm{~s}$, for conventional and graphite sensors respectively. The main factor responsible for the limited lifetime of a sensor is believed to be the loss of one or more of its components while contacting with aqueous solutions. Among all the membranes prepared, the lifetime of the membrane sensors comprising DOP was maximum and found to be 4 and 3 weeks for conventional and graphite sensors respectively. During this lifetime of the sensors, no significant drift in potential was noticed. However, it is important to emphasize that the membranes were stored in a $0.01 \mathrm{M} \mathrm{Cu}^{2+}$ solution when not in use. As can be seen, over the whole concentration range the electrodes reach their equilibrium response in short time. This is most probably due to the fast exchange kinetics of complexation-decomplexation of the copper ion with the ionophore at the test solution-membrane interface.

\section{Effect of pH and sensor selectivity}

The $\mathrm{pH}$ dependence of response of the sensor has been tested in the range of 211 of two $\mathrm{Cu}^{2+}$ concentrations of $1.0 \times 10^{-3}$ and $1.0 \times 10^{-4} \mathrm{M} \mathrm{Cu}^{2+}$. The $\mathrm{pH}$ was adjusted with dilute hydrochloric acid or sodium hydroxide solutions. The potential of the sensor was determined as a function of $\mathrm{pH}$ and the results are shown in Figure 3 for conventional and graphite electrodes respectively. The potential remains constant over the $\mathrm{pH}$ range of $4-7$, which may be taken as the working $\mathrm{pH}$ range of the sensors assembly. The observed drift at higher $\mathrm{pH}$ values could be due to the formation of some hydroxyl complexes of $\mathrm{Cu}^{2+}$ ion in solution. At low $\mathrm{pH}$, the $\mathrm{H}^{+}$ions interference and the membrane sensors responds to the hydrogen ions.

A number of mono, di- and trivalent cations have been tested using the separate solution method (SSM) using conventional and graphite electrodes. The results are given in Table $4 . \quad$ It is evident from the selectivity coefficient data that the sensors exhibit higher preference for copper (II) ion compared with alkali, alkaline earth, transition and heavy metal ions. The selectivity studies were carried out only for sensors, which exhibited the best performance characteristics in terms of working concentration range, slope, response time and life time. The results indicated that, both the electrodes are substantially selective to $\mathrm{Cu}^{2+}$ ions over all the interfering ions studied. It was found that, from Table 3, the conventional electrode exhibits better selectivity than the graphite electrode. 

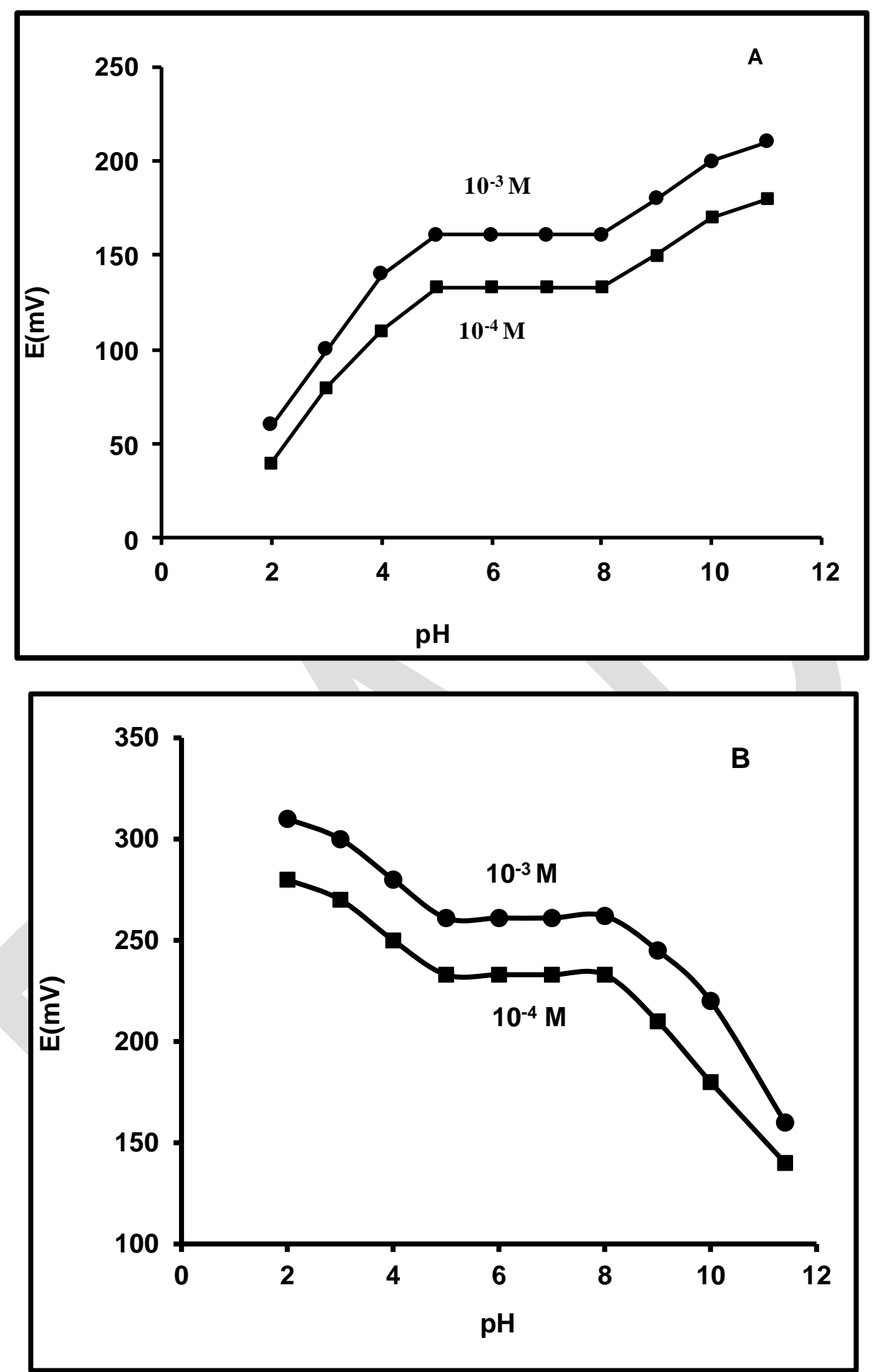

Fig. 3 Effect of pH on potential of copper (A) conventional; and (B) graphite PVC membrane sensor. 
Table 2 Composition of conventional and graphite PVC copper membrane sensors.

\begin{tabular}{|c|ccccc|c|c|}
\hline \multirow{2}{*}{ Membrane } & \multicolumn{5}{|c|}{ Electrode Composition (mg) } & $\begin{array}{c}\text { Conventional } \\
\text { Electrode }\end{array}$ & $\begin{array}{c}\text { Graphite } \\
\text { Electrode }\end{array}$ \\
\cline { 2 - 8 } & Ionophore & PVC & DOP & Additive, \% & $\begin{array}{c}\text { Slope } \\
\text { (mV/decade) }\end{array}$ & $\begin{array}{c}\text { Slope } \\
\text { (mV/decade) }\end{array}$ \\
\hline I & 0.0 & 65.0 & 132.0 & 0 & 0.0 & 0.0 \\
\hline II & 1.0 & 65.7 & 131.5 & 2 & 28.5 & 25.8 \\
\hline III & 3.0 & 66.0 & 132.0 & 5 & 29.5 & 27.8 \\
\hline IV & 5.0 & 67.3 & 133.1 & 7 & 29.1 & 27.1 \\
\hline V & 6.0 & 68.2 & 133.5 & 10 & 29.1 & 27.1 \\
\hline
\end{tabular}

Table 3 Response characteristic of PVC copper membrane sensors.

\begin{tabular}{|c|c|c|}
\hline Parameter $^{\text {a }}$ & Conventional sensor & Graphite sensor \\
\hline Slope, $\mathrm{mV} /$ decade $^{-}$ & $29.5 \pm 0.3$ & $27.8 \pm 0.8$ \\
\hline Correlation coefficient, $(\mathrm{r})$ & 0.998 & 0.996 \\
\hline Lower limit of linear range, $(\mathrm{M})$ & $1 \times 10^{-6}$ & $7 \times 10^{-5}$ \\
\hline Lower limit of detection, (M) & $5 \times 10^{-7}$ & $10^{-6}$ \\
\hline Response time for $10^{-3} \mathrm{M},(\mathrm{s})$ & 10 & 15 \\
\hline Recovery time for $10^{-3} \mathrm{M},(\mathrm{s})$ & 25 & 30 \\
\hline Working range, $\mathrm{pH}$ & $4-7$ & $4-7$ \\
\hline Life span, (week) & 8 & 8 \\
\hline Accuracy $(\%)$ & 99.89 & 100.04 \\
\hline Repeatability, $\mathrm{CV}(\%)$ & 0.9 \\
\hline Between day-variability, $\mathrm{CV}(\%)$ & 0.7 & 1.4 \\
\hline Standard deviation, $\sigma(\%)$ & 1.3 & 1.1 \\
\hline
\end{tabular}

a Average of five measurements

Table 4 Selectivity coefficients of PVC copper membrane sensors.

\begin{tabular}{|l|l|l|}
\hline \multirow{2}{*}{$\begin{array}{l}\text { Interfering ion } \\
\text { (B) }\end{array}$} & \multicolumn{2}{|l|}{ Selectivity coefficient $\left(\mathrm{K}_{\mathrm{Cu}(\mathrm{Pot}), B}\right)^{\mathrm{a}}$} \\
\cline { 2 - 3 } & Conventional electrode & Graphite electrode \\
\hline $\mathrm{Na}^{+}$ & $2.0 \times 10^{-3}$ & $3.2 \times 10^{-2}$ \\
\hline $\mathrm{K}^{+}$ & $4.6 \times 10^{-3}$ & $4.7 \times 10^{-2}$ \\
\hline $\mathrm{Ag}^{+}$ & $5.2 \times 10^{-3}$ & $7.2 \times 10^{-2}$ \\
\hline $\mathrm{NH}^{+}$ & $3.4 \times 10^{-3}$ & $5.4 \times 10^{-2}$ \\
\hline $\mathrm{Cs}^{+}$ & $8.4 \times 10^{-2}$ & $1.3 \times 10^{-2}$ \\
\hline $\mathrm{Pb}^{2+}$ & $6.7 \times 10^{-3}$ & $2.5 \times 10^{-2}$ \\
\hline $\mathrm{Mg}^{2+}$ & $4.6 \times 10^{-4}$ & $1.3 \times 10^{-3}$ \\
\hline $\mathrm{Ca}^{2+}$ & $4.7 \times 10^{-1}$ & $1.6 \times 10^{-1}$ \\
\hline $\mathrm{Co}^{2+}$ & $2.8 \times 10^{-2}$ & $7.1 \times 10^{-2}$ \\
\hline $\mathrm{Cd}^{2+}$ & $5.6 \times 10^{-2}$ & $6.7 \times 10^{-2}$ \\
\hline $\mathrm{Ni}^{2+}$ & $9.1 \times 10^{-2}$ & $9.2 \times 10^{-2}$ \\
\hline $\mathrm{Fe}^{2+}$ & $4.2 \times 10^{-2}$ & $2.5 \times 10^{-2}$ \\
\hline $\mathrm{Sr}^{2+}$ & $1.8 \times 10^{-2}$ & $5.5 \times 10^{-2}$ \\
\hline $\mathrm{Mn}^{2+}$ & $3.6 \times 10^{-2}$ & $2.6 \times 10^{-2}$ \\
\hline $\mathrm{Zn}^{2+}$ & $3.2 \times 10^{-2}$ & $5.6 \times 10^{-2}$ \\
\hline $\mathrm{Ce}^{3+}$ & $2.7 \times 10^{-2}$ & $4.3 \times 10^{-2}$ \\
\hline $\mathrm{Al}^{3+}$ & $1.4 \times 10^{-3}$ & $9.2 \times 10^{-2}$ \\
\hline $\mathrm{Fe}^{3+}$ & $1.2 \times 10^{-}$ & $5.8 \times 10^{-2}$ \\
\hline & \multicolumn{2}{|c}{ average of five measurements } \\
\hline
\end{tabular}

Determination of Copper in waste water

Membrane (III) based conventional

sensor was used for potentiometric determination of $\mathrm{Cu}^{2+}$ ions in some waste water samples obtained from Egyptian copper company. The samples were treated with nitric

Research Journal of Applied Science and Biotechnology, Vol. 3(2), 51-65, 2017.

60 
acid to dissociate the metal complexes. Data spectrometry is agree well with the data obtained (Table 5) using atomic absorption obtained by the proposed method. Table 5 Determination of copper in mineral samples by conventional copper sensor and AAS spectrometry.

\begin{tabular}{|c|c|c|c|c|}
\hline \multirow{3}{*}{ Samples } & \multicolumn{4}{|c|}{ Copper content, $^{\text {a }}$} \\
\cline { 2 - 5 } & \multicolumn{2}{|c|}{ Potentiometry } & \multicolumn{2}{c|}{ AAS } \\
\cline { 2 - 5 } & $\begin{array}{c}\text { Waste Water, } \\
\mathbf{~ m g / l}\end{array}$ & $\begin{array}{c}\text { Metal Alloys, } \\
\mathbf{~ m g / g}\end{array}$ & $\begin{array}{c}\text { Waste Water, } \\
\mathbf{~ m g / l}\end{array}$ & $\begin{array}{c}\text { Metal Alloys, } \\
\mathbf{~ m g / g}\end{array}$ \\
\hline 1 & $98.7 \pm 0.6$ & $112.1 \pm 0.2$ & $96.3 \pm 1.2$ & $110.8 \pm 0.9$ \\
\hline 2 & $110.7 \pm 0.5$ & $126.5 \pm 0.9$ & $109.5 \pm 0.8$ & $124.4 \pm 0.7$ \\
\hline 3 & $105.5 \pm 0.9$ & $121.3 \pm 0.1$ & $104.8 \pm 0.7$ & $119.6 \pm 0.8$ \\
\hline 4 & $108.9 \pm 0.8$ & $129.4 \pm 0.4$ & $106.4 \pm 0.8$ & $127.8 \pm 0.9$ \\
\hline 5 & $113.6 \pm 0.4$ & $124.1 \pm 0.3$ & $112.9 \pm 0.7$ & $122.3 \pm 0.8$ \\
\hline 6 & $109.2 \pm 0.7$ & $115.2 \pm 0.7$ & $108.1 \pm 0.8$ & $114.6 \pm 0.9$ \\
\hline
\end{tabular}

a Average of five measurements

\section{Determination of copper in alloys}

The copper content of six metal alloys taken from Egyptian copper company were studied. The contents of copper were measured by direct potentiometry using conventional sensor based on membrane (III). The results obtained show an average $\mathrm{Cu}$ content ranging from $150-350 \mathrm{mg} / \mathrm{g}$ of alloys. Similar results are obtained using atomic absorption spectrometry (Table 5).

Determination of copper in pharmaceutical formulations

The validity of the proposed potentiometric methods for determining copper was assessed by measuring the range, lower limit of detection (LOD), accuracy (recovery), precision or repeatability $\left(\mathrm{CV}_{\mathrm{w}}\right)$, between-day variability

Table 6 Determination of copper in some pharmaceutical preparations using
$\left(\mathrm{CV}_{\mathrm{b}}\right)$, linearity (correlation coefficient) and sensitivity (slope). Data obtained on five batches (five determinations each) using the calibration graph method show results with average recoveries of 99.89 and $100.04 \%$ and mean standard deviations of \pm 1.0 (Table 3 ). Copper was also determined in various dosage forms. The results obtained with conventional copper sensor, based membrane sensor for determination of copper amount in some pharmaceutical samples from local pharmacy are shown in Table 6. As it is seen, the results are in satisfactory agreement with the atomic absorption method and with the stated content on capsules.

conventional copper sensor and AAS spectrometry.

\begin{tabular}{|c|c|c|c|}
\hline Trade name and source & \multirow{2}{*}{$\begin{array}{c}\text { Nominal content } \\
\text { (mg capsule }^{-1} \text { ) }\end{array}$} & \multicolumn{2}{|c|}{ Copper content $^{\text {a }}$} \\
\cline { 3 - 4 } & Potentiometry & AAS \\
\hline $\begin{array}{c}\text { Enrich } \\
\text { (Marc. Pharm. Ind., Egypt) }\end{array}$ & 2.50 & $100.4 \pm 0.5$ & $98.1 \pm 0.4$ \\
\hline $\begin{array}{c}\text { Theragran Hematinic } \\
\text { (Bristol-Myers Squibb, Egypt) }\end{array}$ & 0.67 & $99.5 \pm 0.7$ & $98.5 \pm 0.3$ \\
$\begin{array}{c}\text { Mamyvit } \\
\text { (Multi- Apex Pharm) }\end{array}$ & 4.00 & $100.2 \pm 0.3$ & $98.3 \pm 0.5$ \\
\hline
\end{tabular}

61 
Comparison with Other Reported Copper Sensors

Table 1, shows a comparison of the performance characteristics of some previously reported $\mathrm{Cu}^{2+}$ membrane sensors with those described in this work.

Selectivity coefficients of the proposed sensors towards some potential interfering ions were in the order of $10^{-3}$ or smaller, indicating superior selectivity over other sensors (Gupta, et al. 2003; Abbaspour, and Kamyabi, 2002; Kamata, et al. 1989; Gholivand, and Nozari, 2001; Shamsipur, et al. 1999; Gismera, et al. 2003; Brzozka, 1988). Wider working concentration range and lower detection limit are also offered by the proposed sensors compared with some of those previously suggested (Abbaspour, and Kamyabi, 2002; Shamsipur, et al. 1999; Gismera, et al. 2003)

\section{REFERENCES}

Abbaspour, A. and M. A. Kamyabi, (2002). Copper(II)-selective electrode based on dithioacetal Anal. Chim. Acta, 455, 225-231.

Abbaspour, A., S. M. M. Moosavi, (2002). Chemically modified carbon paste electrode for determination of copper(II) by potentiometric method. Talanta, $56,91-96$

Ahmed, M. J., Jahan, I., and Banoo, S., (2002). A Simple Spectrophotometric Method for the Determination of Copper in Industrial, Environmental, Biological and Soil Samples Using 2,5-Dimercapto-1,3,4thiadiazole Anal. Sci., 18, 805810. Ajay K. Jain, Vinod K. Gupta, Lok P. Singh and U. Khurana, (1997). Macrocycle Based Membrane Sensors for the Determination of Cobalt(II) lons, , Analyst, 122, 583-586

Ali, T. A., Mohamed, G.G., Othman, A. R (2015). Design and Construction of New Potentiometric Sensors for Determination of Copper(II)
Ion Based on Copper Oxide

Nanoparticles. Int. J. Electrochem. Sci., 10, 7275 7291.

Asan, A., Andac, M. and Isildak. I. (2001), Flow-injection spectrophotometric determination of copper(II) ion at low microgram L-1 levels using 4benzylpiperidinedithiocarbamate . Anal. Sci., 17, 1125-7.

Brzozka, Z. (1988). Transition metal ionselective membrane electrodes based on complexing compounds with heteroatoms. Part II. Complexing compounds containing sulphur atoms Analyst, 113, 1803-1805. "CEM Microwave Digestion Application Manual", CEM Corporation, USA, (1994).

Dadfarnia, S. and M. Shamsipur, (1992). Specific membrane transport of copper(II) ion by a cooperative carrier composed of 1,7-diaza15-crown-5 and palmitic acid. J. Membr. Sci., 75, 61-68.

Firooz, A., M. Mazloum, J. Safari and M. Amini, (2002). Coated-wire 
copper(II)-selective electrode based on phenylglyoxal-alphamonoxime ionophore. Anal. Bioanal. Chem., 372, 718-722.

Gholivand, M. B. and N. Nozari (2001). Copper(II)-selective electrode using 2,2'-dithiodianiline as neutral carrier. Talanta, 54, 597602.

Gismera, M. J., M. A. Mendiola, J. R. Procopio, and M. T. Sevilla, (1999). Copper potentiometric sensors based on copper complexes containing thiohydrazone and thiosemicarbazone ligands. Anal. Chim. Acta, 385, 143149.

Gismera, M. J., J. R. Procopio, M. T. Sevilla, and L. Hernaadez, (2003). Copper (II) ion-selective electrodes based on dithiosalicylic and thiosalicylic acids. Electroanalysis, 15, 126132.

Greenwood N.N. and A. Earnshow,(1984). "Chemistry of Elements", Pergamon Press New York.

Gupta, K. C. and M. J. D'arc, (2001). Effect of concentration of ion exchanger, plasticizer and molecular weight of cyanocopolymers on selectivity and sensitivity of $\mathrm{Cu}(\mathrm{II})$ ion selective electrodes Anal. Chim. Acta, 437, 199-216.

Gupta, K. C. and M. J. D'arc, (2000). Performance evaluation of copper ion selective electrode based on cyanocopolymers Sens. Actuators B, 62, 171-176.
Gupta, V. K. R. Prasad, and A. Kumar (2003). Preparation of ethambutol-copper(II) complex and fabrication of PVC based membrane potentiometric sensor for copper. Talanta, 60(1):149-160.

Gupta, V. K. , A. K. Jain, G Maseshwari, H. Lang, and Z. Ishtaiwi, (2006). Copper(II)-selective potentiometric sensors based on porphyrins in PVC matrix. Sens. Actuators B, 117, 99-106.

Hassan S. S. M. (1984). "Organic Analysis Using Atomic Absorption Spectrometry", Ellis Horwood, Chichester, England.

Hassan, S. S. M., E. A. Elnemma, and A. H. K. Mohamed, (2005). Novel potentiometric copper (II) selective membrane sensors based on cyclic tetrapeptide derivatives as neutral ionophores. Talanta, 66, 10341041.

Hassan, S.S.M., Saleh, M.B., Abdel Gaber, A.A. and Abdel kream, N.A., (2003). DDB liver drug as a novel ionophore for potentiometric barium (II) membrane sensor. Talanta, 59, 161-166.

Hassan, S. S. M., S. A. M. Marzouk, (1994). A novel ferroin membrane sensor for potentiometric determination of iron. Talanta, 41, 891-899.

Jacintho, A. O., Zagatto, E. A. G., Bergamin, H., Krug, F. J., Reis, B. F., Brunsand, R. E.,and 
Kowalski, B.R., (1981). Flow

injection systems with

inductively-coupled argon

plasma atomic emission

spectrometry: Part 1.

Fundamental Considerations

Anal. Chim. Acta, 130, 243-255.

Jain, A. K., V. K. Gupta, L. P. Singh, and J.

R. Raisoni, (2005). Chelating ionophore based membrane sensors for copper(II) ions. Talanta, 66, 1355-1361.

Janata, J. and Růžička, J. (1982). Combination of flow injection analysis and voltammetry. J., Anal. Chim. Acta, 139, 105-115.

Kamata, S., H. Murata, Y. Kubo, and A. Bhale, (1989). Copper(II)selective membrane electrodes based on o-xylylene bis(dithiocarbamates) as neutral carriers Analyst, 114, 1029-1031.

Marston H.R. (1952). Cobalt, copper and molybdenum in the nutrition of animals and plants. Physiol Rev., 32(1), 66-121.

Marzouk, S. A. M., W.T. Al-Ariqui, and S. S. M. Hassan, (2003). A novel 1,10-phenanthroline-sensitive membrane sensor for potentiometric determination of $\mathrm{Hg}$ (II) and $\mathrm{Cu}(\mathrm{II})$ cations. Anal. Bioanal. Chem., 375, 11861192.

Poursaberi, T., L.B. Hajlagha, M. Yousefi, S. Rouhani, M. Shamsipur, R. M. Kargar, A. Moghimi, H. Aghabozorg, M. R . and Ganjali, (2001). The Synthesis of a New Thiophene-Derivative
Schiff's Base and Its Use in Preparation of Copper-lon Selective Electrodes. Electroanalysis, 2001, 13, 15131517.

Reynold, J. E. F. (ed) (1993). "Martindale The Extrapharmacopoeia", The Pharmaceutical Press, London $30^{\text {th }}$ ed., p. 924.

Richter, E.M., Augelli, M.A., Magarotto, S., and Angnes, L., (2001). Compact Disks, a New Source for Gold Electrodes. Application to the Quantification of Copper by PSA Electroanalysis, 13, 760-764.

Rizk, M. S., Y. M. Issa, A. F. Shoukry, M. M. Abdel-Aal, (1994). New Ampicillin Selective Plastic Membrane and Coated Metal Electrodes Based on Ampicillinium Phosphotungstate Ion pair. Anal. Lett. 27, 10551065.

Rizk, N. M. H. and A. H. M. Othman, (2005). Membrane sensors for selective determination of thiopental. Anal. Sci., 21, 107-110.

Rizk, N. M. H., S. S. Abbas, S. M. Hamaza, and Y.M. Abdel-karem, (2009). Thiopental and Phenytoin as Novel lonophores for Potentiometric Determination of Lead (II) lons. Sensors, 9, 18601875.

Rizk, N. M. H., S. S. Abbas, F. A. El-Sayed and A. Abo-Baker, (2009). Novel lonophore for the Potentiometric Determination of Cetirizine Hydrochloride in 
Pharmaceutical Formulations and Human Urine. Int. J.

Electrochem. Sci., 4, 396-406.

Sadeghi, S. M. Eslahi, M.A. Naseri, H. Naeimi, $H$ Sharghi, and $A$. Shameli, (2003). Copper ion selective membrane electrodes based on some Schiff base derivatives. Electroanalysis, 15, 1327-1333.

Shamsipur, M., S. Rouhani, M. R. Ganjali, H. Eshghi, and H. Sharghi, (1999). Copper (II)-Selective Membrane Electrode Based on a Recently Synthesized Macrocyclic Diamide Microchem. J., 63, 202-210.

Sahan S., Şahin, U., (2010). Determination of Copper (II) Using Atomic Absorption Spectrometry and Eriochrome Blue Black $\mathrm{R}$ Loaded Amberlite XAD-1180 Resin. Soil Air Water 38(5-6):485 - 491.

Stankovic, D. Roglic, G. Jelena Mutic, J., Ivan Andjelkovic, I., Markovic, M. and Dragan Manojlovic, (2011). Determination of Copper in Water by Anodic Stripping Voltammetry Using Cu-DPABANA/GCE Modified Electrode. Int. J. Electrochem. Sci., 6, 5617 5625.

Umezawa, Y., P. Buhlmann, K. Umezawa, K. Tohda, and S. Amemiya, (2000). Potentiometric Selectivity Coefficients of IonSelective Electrodes. Part I. Inorganic Cations. Pure Appl. Chem., 72, 1851-2082.
Wolf, W. R. and K. K. Stewart, (1979). Automated multiple flow injection analysis for flame atomic absorption spectrometry. Anal. Chem., 51, 1201-1205.

Yoshimoto, S., H. Mukai, T. Gitano, and Y. Sohrin, (2003). Copper(II)selective membrane electrode based on hydrotris(3isopropylpyrazolyl)methane in a poly(vinyl chloride) matrixAnal. Chim. Acta, 494, 207-213.

Zagatto, E. A. G., Jacintho, A. O. Krug, F. J. and Reis, B. F. (1983). Flow injection systems wiht inductively-coupled argon plasma atomic emission spectrometry: Part 2. The generalized standard addition method. Anal. Chim. Acta, 145, 169-178. 